\title{
Phosphatidylcholine- \\ Lysophosphatidylcholine Cycle Pathway Enzymes in Rabbit Lung. II. Marked Differences in the Effect of Gestational Age on Activity Compared to the CDP-Choline Pathway
}

\author{
FRANCIS H. C. TSAO ${ }^{(30)}$ AND RICHARD D. ZACHMAN \\ Department of Pediatrics of the University of Wisconsin, and The Wisconsin Perinatal Center, \\ Madison, Wisconsin, USA
}

\begin{abstract}
Summary
Lysophosphatidylcholine (lysoPC), a breakdown product of phosphatidylcholine (PC), might be important in pulmonary $\mathrm{PC}$ synthesis through fatty acid exchange reactions. This study defines the levels of three of the enzymes of the PC-lysoPC cycle pathway (lysophospholipase (LPL) (EC. 3.1.1.5), lysophosphatidylcholine-lysophosphatidylcholine acyltransferase (LAT), and acyl-CoA lysophosphatidylcholine acyltransferase (acryl-CoA LAT) (EC. 2.3.1.23)) in developing fetal rabbit lung and compares them with the enzymes of the CDP-choline synthetic pathway (choline kinase (CK) (EC. 2.7.1.32), phosphorylcholine cytidyl transferase (CyT) (EC. 2.7.7.15), and phosphorylcholine glyceride transferase (PCGT) (EC. 2.7.8.2)).

Lung homogenates of fetal rabbits of known gestation, new. born, and adult rabbits were used for the enzyme, protein, and phospholipid analyses. Total lung phospholipid, PC, and protein increased with gestational age. Thirty days' gestation, newborn, and maternal lung activities of CK, CyT, and PCGT had decreased to only $50 \%$ of their activities at 22-26 days' gestation. In contrast, LPL and LAT activities increased 4-5fold from 22-26 days to 30 days' gestation, and increased further in the newborn lung, finally to a level matching maternal lung (about 8-10-fold higher than the 22-26 days' gestation activities). The microsomal acyl-CoA LAT also showed a similar increasing activity with gestational age.

In fetal rabbit lung, enzymic activities for the apparent major PC synthetic pathway decreased. In contrast, the marked increases in LPL, LAT, and acyl-CoA LAT activities with increasing gestational age and at birth suggests importance of the PClysoPC cycle pathway in regulating synthesis and turnover with maturation.
\end{abstract}

\section{Speculation}

There are marked increases in lung lyso PC cycle pathway enzymes with gestational and postnatal ages. This finding suggests that this cycle pathway is very important in pulmonary maturation and in the formation of surface-active dipalmitoylPC.

Study of the development of pulmonary lipids of mammalian lung showed that the concentration of total phospholipids of the fetus increased with gestational age of all species studied (13). Among the total lipids, PC, the major lung surfactant phospholipid, increased significantly whereas other nonsurfactant phospholipids remained unchanged at late gestational age or after term $(12,25)$. Therefore, the synthesis of lung PC has been considered as an important factor in relation to the lung maturation.

Lung PC is synthesized mainly from the de novo pathway; namely, the CDP-choline pathway $(6,9)$. It can also be resynthesized from a PC-lysoPC cycle pathway where PC is deacylated to form lysoPC, which is reacylated back to PC. Two mechanisms for the reacylation are possible: (1) acylation with acyl-CoA as described by Lands (17), or (2) a transacylation of 2 molecules of lysoPC observed by Erbland and Marinetti (7).

The activities of the CDP-choline pathway enzymes at different stages of developing mammalian lung have been studied. A decrease of the activity of phosphorylcholine glyceride transferase during the devclopment of fetal rabbit has been reported (13). A decrease of this enzyme activity (27) as well as choline kinase activity (26) also occurs in human fetal lung at late gestational ages. However, conflicting results were reported in developing rat $(10,24)$ and developing lamb (4). All of these results showed an increase in the incorporation of precursors into lung PC or an increase in the activities of this pathway enzymes at late gestational ages or at term of these animals.

Although the PC-lysoPC cycle pathway has been suggested as a possible route to remodel lung PC $(1-3,11,14-16,23)$, its role in remodeling lung $P C$ to supply dipalmitoyl-PC is not well understood. Transacylation in this pathway in the developing lung has only recently been studied (15) by following the incorporation of lysoPC into PC using developing rabbit lung slices. The acylation of lysoPC in the developing rabbit lung microsomes was also recently reported (19).

In this paper we report the effect of gestational age on the activities of lysophospholipase and lysoPC acylation enzymes (LAT and acyl-CoA LAT) of the PC-lysoPC cycle pathway, activities of CDP-choline pathway enzymes, and the content of phospholipids and proteins of the developing fetus, newborn, and adult rabbit lung.

Our results confirm some earlier observations that the activities of CDP-choline pathway enzymes, CK, CyT, and PCGT, decrease or remain unchanged with increasing gestational ages $(13,26,27)$. In contrast, the activities of the PC-lysoPC cycle pathway enzymes increase markedly at late gestational age, and continue to increase after birth to the adult level. Their role in relation to the maturation of rabbit lung is discussed.

\section{MATERIALS AND METHODS}

\section{ANIMALS AND PREPARATION OF LUNG HOMOGENATE}

A pregnant (New Zealand) rabbit of known gestation within + hr was anesthetized with $10-15 \mathrm{mg}$ sodium pentobarbital/ 
pound. The fetus was removed from the amniotic sac and fetal lung, as well as maternal lung, was immediately transferred to $0.9 \%$ saline solution chilled in ice before fetal respiratory movement began. Subsequently, bronchial tissue of the pooled fetal lung and the maternal lung was removed before weighing. The lung tissue was sliced and rewashed with saline and water to remove blood. It was then homogenized in a Potter-Elvehjem homogenizer (clearance $0.005-0.007$ inch) in 10 volumes of $0.25 \mathrm{M}$ sucrose with 10 strokes at high speed. All processes were carried out at $0^{\circ}$. The homogenate was used for the assays of the enzymes of PC-lysoPC cycle pathway, enzymes of CDP-choline pathway, and analyses of protein and phospholipid content. With one exception, the lungs of 3-10 fetuses of two different does at each gestational age were assayed and the average reported. The newborn (less than 24-hr old) values were the average of 6 pairs of lungs; 12 adults were used. Microsomes were prepared by the procedure described previously (22). All analyses were carried out in duplicate.

\section{ENZYME, PROTEIN, AND PHOSPHOLIPID ANALYSIS}

The procedures for the assay of the enzymes, CK, Cyl, PCGT, LPL, LAT, and acyl-COA LAT, were as detailed elsewhere $(22)$. The phospholipids and microsomal proteins analyses have also been described (22). The protein concentration of the lung homogenate was determined by the biuret method (18) and bovine serum albumin (Fraction V, Miles Laboratories. Kankakee, III.) was used as a standard.

\section{RESULTS}

\section{PROTEIN AND PHOSPHOLIPID ANALYSES}

Protein. The quantity of protein per g wet tissue increased with gestational age and reached a maximum in the newborn that matched the maternal level (Fig. 1A). This newborn-adult lung protein level $(139.17 \pm 16.53 \mathrm{mg} / \mathrm{g}$ wet tissue) was about $3-$ fold higher than that of 20 -day fetus $(46.93 \pm 4.57 \mathrm{mg} / \mathrm{g}$ wet tissue). A lag period was observed between 24 and 30 days of gestation.

Phospholipids. The concentration of total phospholipids per g wet tissue also increased with gestational age (Fig. 1B). The most significant change was from 30 days of gestation (13.46 \pm $2.29 \mu \mathrm{mol} / \mathrm{g}$ wet tissue) through newborn $(19.22 \pm 2.02 \mu \mathrm{mol} / \mathrm{g}$ wet tissue) to the maternal level $(27.11 \pm 3.23 \mu \mathrm{mol} / \mathrm{g}$ wet tissue). Insignificant changes were observed between 24 and 30 days of gestation, as similarly observed for protein concentration (Fig. 1A). Phosphatidylcholine was about $50-60 \%$ of the total phospholipids in all developing lung and showed a pattern similar to total phospholipids. However, phosphatidylethanolamine (PE) and sphingomyelin (SM) were nearly constant before term and then increased to the maternal level $(5.50 \pm 0.95 \mu \mathrm{mol} / \mathrm{g}$ wet tissue for PE and $3.76 \pm 0.75 \mu \mathrm{mol} / \mathrm{g}$ wet tissue for SM).

\section{ENZYME ACTIVITY}

CDP-Choline Pathway Enzymes. The specific activities of all three enzymes of the CDP-choline pathway decreased after 26 days of gestation (Fig. 2). The CK specific activity at 26 days of gestation was $3.76 \pm 1.59 \mathrm{nmol}$ phosphorylcholine/mg protein/ min versus $2.15 \pm 0.75$ at the maternal level; CyT was $0.25 \pm$ $0.02 \mathrm{nmol} \mathrm{CDP}$-choline $/ \mathrm{mg}$ protein $/ \mathrm{min}$ versus $0.13 \pm 0.02$; and $\mathrm{PCG}$ was $0.29 \mathrm{nmol} \mathrm{PC} / \mathrm{mg}$ protein $/ \mathrm{min}$ versus $0.14 \pm 0.03$. All newborn and maternal level specific activities had decreased to about $50 \%$ of their values at 26 days of gestation.

At optimum $\mathrm{pH}$ conditions for each enzyme, the specific activity of CK was 10-20-fold higher than the specific activities of CyT and PCGT at all gestational ages. At pH $7.4,37^{\circ}$, and saturating substrate concentrations, the relative rates of these three enzyme activities in adult lungs were $\mathrm{CK}>\mathrm{PCGT}>\mathrm{CyT}$ (Table 1)

Phosphatidylcholine-Lysophosphatidylcholine Cycle Enzymes. The specific activities of LPL and LAT at 22-26 days of gesta-
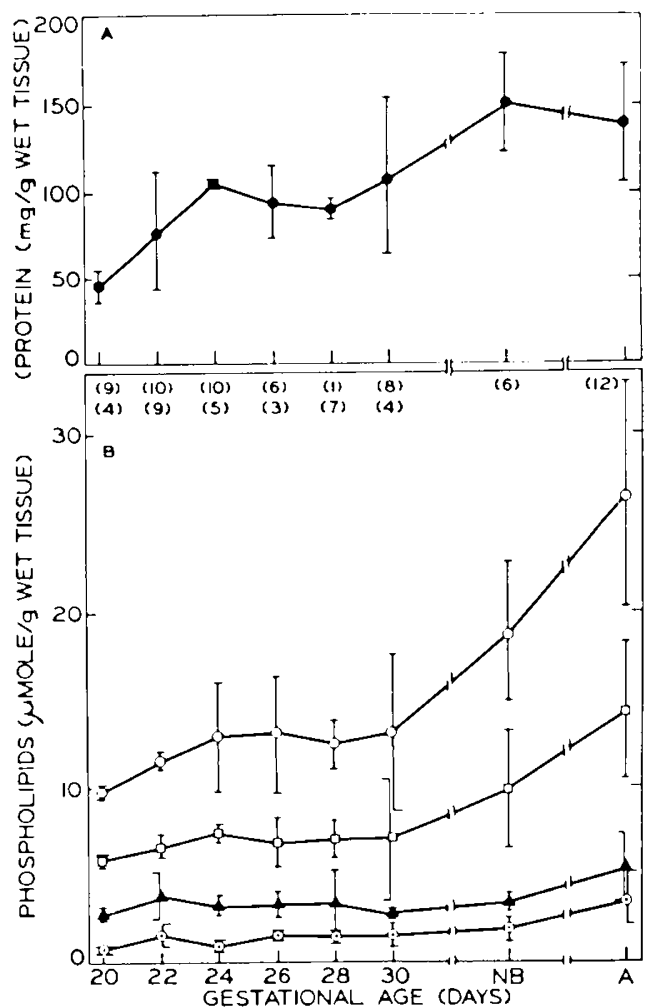

Fig. 1. A: effect of gestational age on the protein concentration (๑) in the rabbit lung of fetuses, newborns $(N B)$, and adult $(A)$. B: effect of gestational age on the concentration of total phospholipids $(O)$, phosphatidylcholine $(\square)$, phosphatidylethanolamine $(\boldsymbol{\Delta})$, and sphingomyelin $(\odot)$ in the rabbit lung of fetuses, newborns, and adult. The numbers in parentheses represent litters from two different mothers. The mean values of all lungs and \pm 2 SD (bracketed) are shown in this and all subsequent figures.

tion were only $10 \%$ of the maternal activities $(14.39 \pm 3.73$ nmol free fatty acids (FFA)/mg protein/min for LPL and $7.06 \pm$ $1.78 \mathrm{nmol} \mathrm{PC} / \mathrm{mg}$ protein/min for LAT) (Fig. 3). LPL increased 3 -fold from 26 days of gestation to 30 days of gestation (1.79 \pm 0.21 versus $6.62 \pm 0.63 \mathrm{nmol} \mathrm{FFA} / \mathrm{mg}$ protein/min), then increased further to maternal levels. LAT also increased 3 -fold from 26 to 30 days of gestation $(0.46 \pm 0.19$ versus $1.66 \pm 0.11$ $\mathrm{nmol} \mathrm{PC} / \mathrm{mg}$ protein/min), increased further in newborn lung $(3.09 \pm 1.04 \mathrm{nmol} \mathrm{PC} / \mathrm{mg}$ protein/min), and nearly doubled again in maternal lung. The activity of microsomal acyl-CoA LAT also increased with gestational age as similar as LAT (Fig. $3 A)$.

\section{DISCUSSION}

The regulatory mechanism of lung $P C$ synthesis is not known. In addition to the de novo CDP-choline pathway, the PC-lysoPC cycle pathway may be an alternate crucial route of regulation. To evaluate indirectly the improtance of cycle pathway enzymes in relation to lung maturation, we studied LPL, LAT, and acylCOA LAT activities in the developing rabbit lung homogenates and microsomal fraction and compared them with newborn and adult values.

The content of protein, total phospholipids, and PC per g wet lung tissue increased gradually with maturation, despite an apparent lag between 24 and 30 days of gestation (Fig. 1). Although the lag in lung phospholipid content was not observed by others (13), the amount of lung PC in 20-day fetuses and the adult was almost the same as calculated from both laboratories (20-day fetus; $6.1 \mu \mathrm{mol} / \mathrm{g}$ wet (13) versus $5.9 \mu \mathrm{mol} / \mathrm{g}$ wet (our data) and adult: 13.5 versus 14.6 ).

The somewhat conflicting results of the enzyme activities of CDP-choline pathway in the developing mammalian lung re- 


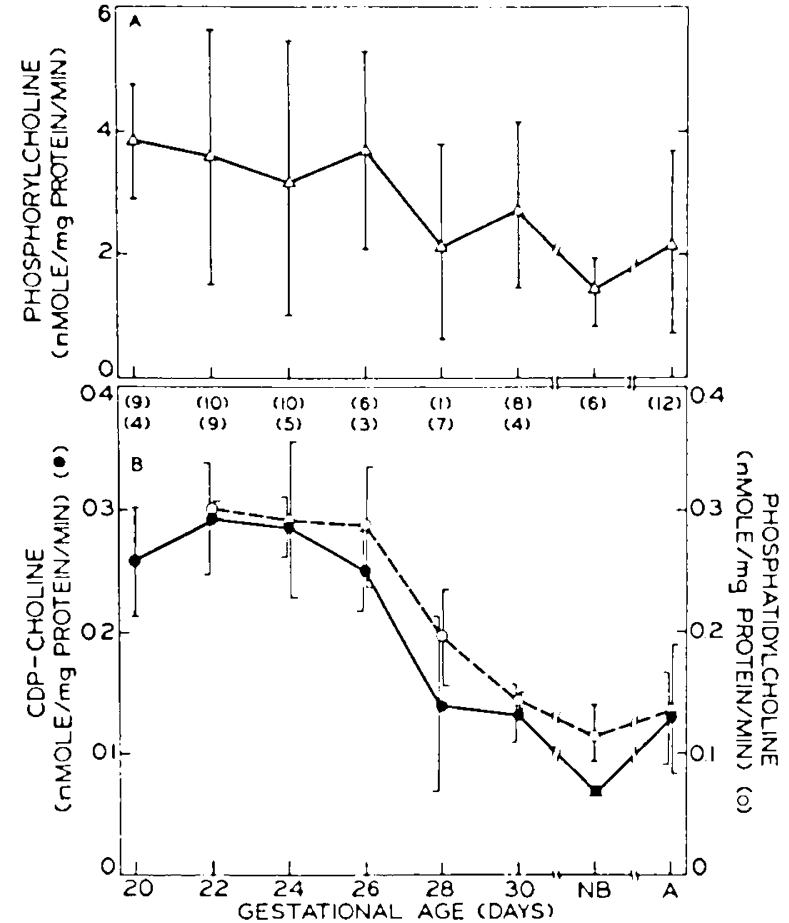

Fig. 2. A: the enzymic activity of choline kinase $(\triangle)$ in the rabbit lung homogenate of developing fetuses, newborns $(N B)$, and adult $(A)$. The reaction mixture contained $2-4 \mathrm{mg}$ protein of the homogenate, $2 \mathrm{mIl}$

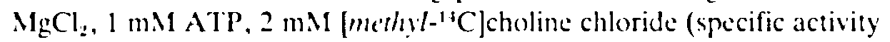
$\left.1 \times 10^{6 \mathrm{cmm}} / \mu \mathrm{mol}\right)$, and $0.1 \mathrm{M}$ Tris- $\mathrm{HCl}(\mathrm{pH} / 8.3)$ in a final volume of $1.0 \mathrm{ml}$. The reaction was carricd out at $37^{\circ}$ for $15 \mathrm{~min}$. B: the enzymic activities of phosphorylcholine cytidyl transferase $(C y T)(\bullet)$ and phosphorylcholine glyceride transferase (PCGT) $(O)$ in the rabbit lung homogenate of developing fetuses, newborns, and adult. For CyT, the reaction mixture contained $2-4 \mathrm{mg}$ protein of the homogenate, $1 \mathrm{mill}[1$. $2-{ }^{14} \mathrm{C} \mid \mathrm{phosphory}$ kholine (specific activity $3 \times 10^{5} \mathrm{cpm} \mu \mathrm{mol}$ ), $1.5 \mathrm{mil}$ . $\mathrm{MgCl}$ and CTP, and $0.1 \mathrm{M}$ Tris-succinate (pH 6.8) in a final volume of $1.0 \mathrm{ml}$. For PCGT, the reaction mixture contained $2-4 \mathrm{mg}$ protein of the homogenate, $59 \mathrm{mMl} \mathrm{MgC1}, 0.44 \mathrm{mM} C D P-\left(1,2-{ }^{14} \mathrm{C} / \mathrm{choline}\right.$ (specific activity $3 \times 10^{5} \mathrm{cpm} / \mu \mathrm{mol}$ ), and $(0.1+\mathrm{M}$ Tris- $\mathrm{HCl}(\mathrm{pH} 8.3)$ in a final volume of $1.7 \mathrm{ml}$. Both reactions were carried out at $37^{\circ}$ for $1.5 \mathrm{~min}$.

Table 1. Specific activities of choline kinase (CK), phosphoryldholine cytidyltransferase $(C y T)$, and phosphorylcholine glyceride transferase ( $P(G T)$ at pll 7.7 in adult

$\begin{array}{cc}\text { Enzyme } & \begin{array}{c}\text { Specific activity' }(\text { mole product } 2 / m g \\ \text { protein } / \min ) \times 10\end{array} \\ \text { CK } & 37.30 \pm 6.07 \\ \text { CyT } & 0.53 \pm 0.02 \\ \text { PCGT } & 1.89 \pm 0.02\end{array}$

1 Mean values $\pm \mathrm{SD}$.

2 The product is represented as $(K$, phosphorylcholine; C $\mathrm{TT}, \mathrm{CDP}$ choline; PCGT, phosphatidylcholine.

ported from several laboratories $(4,8,10,13,24,26,27)$. prompted us to determine these enzymes in parallel with the PClysoPC cycle pathway enzymes in the developing rabbit lung homogenate. PCGT showed higher specific activity at early gestational ages (22-26 days) than late gestational ages and maternal levels (Fig. 2B), which agrees with previous data in rabbit (13) and human lung (27). CK in rabbit lung homogenate also showed a decreasing enzyme specific activity with increase of gestational ages (Fig. $2 A$ ), similar to observations from the developing human lung (26) and developing rat lung (24). In addition, CyT specific activity (the second enzyme of CDP-

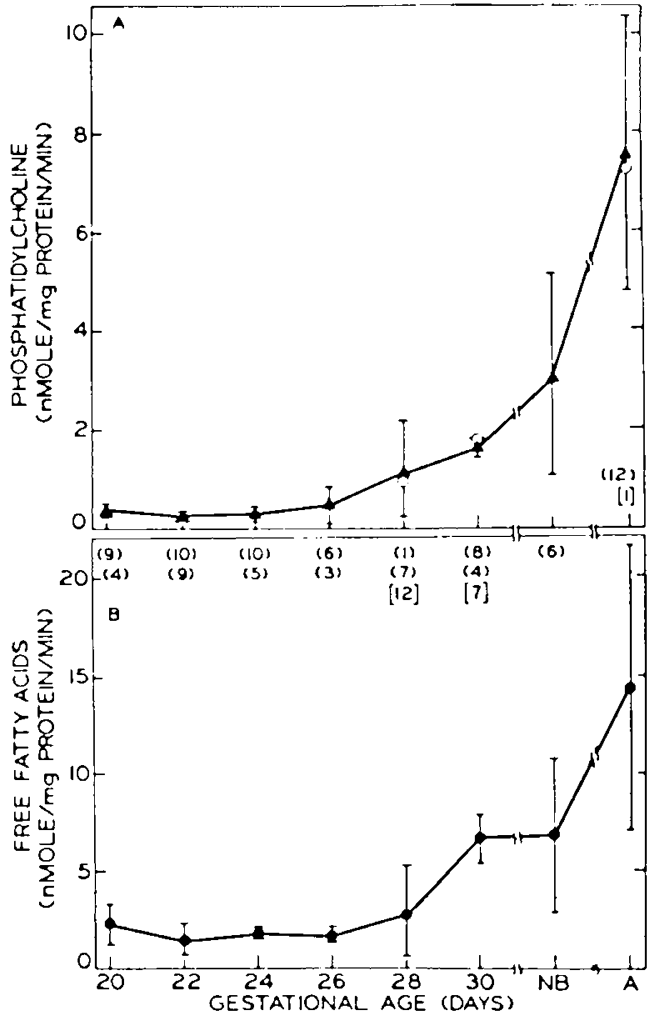

Fig. 3. A: the enzymic activity of lysophosphatidylcholine-lysophosphatidylcholine acyltransferase $(\mathrm{LAT})(\boldsymbol{\Delta})$ and acyl-CoA LAT $(\mathrm{O})$ in the rabbit lung homogenate and microsomes of developing fetuses, newborns $(N B)$, and adult $(A)$. For LAT the reaction mixture contained $0.3-0.5 \mathrm{mg}$ protein of the homogenate, $0.4 \mathrm{mMl} 1-\left[1-1^{14} \mathrm{C}\right]$ palmitoyl-2lysophosphatidylcholine (specific activity $\left.1 \times 10^{5} \mathrm{cpm} / \mu \mathrm{mol}\right), 0.15 \mathrm{M}$ $\mathrm{NaCl}$, and $0.1 \mathrm{M}$ Tris- $\mathrm{HCl}$ (pH 8.0). The reaction was carricd out at $37^{\circ}$ for $5 \mathrm{~min}$. For acyl-CoA LAT, the reaction was at pH 7.4 and contained $0.2 \mathrm{mg}$ microsomal proteins and $0.1 \mathrm{mM}$ palmitoyl-CoA; the rest of the conditions were the same as for LAT. Microsomes of 28-day and 30-day fetuses and the adult were prepared from 12 litters, 7 litters, and 1 adult, respectively. B: the enzymic activity of lysophospholipase (LPL) $(\bullet)$ in the rabbit lung homogenate of developing fetuses, newborns, and adult. The reaction conditions for $L P L$ were the same as for $L A T$.

choline pathway) also decreased with increasing gestational age in developing rabbit lung (Fig. 2B). If content of protein is corrected for, the decrease of the enzyme specific activity may be due to an increase of the protein concentration. Recently. Rooney et al. (19) also observed a decrease of the specific activity of CK, PCG', and CyT, as well as glycerophosphate phosphatidyltransferase (EC. 2.7.8.5) with increasing gestational age. except that they found increasing PCGT and CyT activities in the newborn lung which were not observed in our study and those of others (21).

These conflicting results for CDP-choline pathway enzymes have several possible explanations. In some instances, the conflicting results might be due to species differences in the charatteristics of the CDP-choline pathway. Another possible explanation for some discrepency is the different experimental conditions used. It is obvious that experimental conditions do have an effect on these enzymes. For example, in one report. PCG' specific activity remained constant in rabbit lung microsomes throughout gestation (21), whereas with lung slices, PCGT activity increased throughout gestation (15).

At optimum ph for enzyme activity, we found that $\mathrm{CK}$ had a reaction rate 1() -fold higher than the relative rates of $\mathrm{C} Y \mathrm{~T}$ and PCGT (Fig. 2). This did not vary in either fetal or adult rabbit lung homogenates. However, at pl 7.4 the specific activity of Cyl was less than that of PCGT or CK (Table 1), contrary 
to the results reported previously (8) which showed that monkey lung PCGT had the lowest relative activity.

In contrast to the CDP-choline pathway enzymes, the specific activities of lysophospholipase and acyltransferases of PClysoPC cycle pathway increased markedly at late gestational age and after term (Fig. 3). The results show an almost 2()-fold increase of the specific activity from fetuses of 24-26 days of gestational age to the adult. An ATP-dependent acylation pathway was also demonstrated in the fetal microsomal fraction of rabbit lung that increased with maturation (Fig. $3 A$ ) as also observed by Rooncy et al. (19). Similar increasing activities of LPL and microsomal acyl-CoA LAT were also observed in the developing rat lung (5). In contrast, the activity of the transacylation of lysoPC (LAT) in the fetal rat lung was higher than that of the adult (5). It is not known whether these discrepant results of rat and rabbit were because of species differences or experimental conditions.

The CDP-choline pathway enzymes are certainly present in the rabbit lung throughout the span of gestational age (at least after 22 days). Their activities apparently decrease with maturation. An increase of the specific activity of phosphatidic acid phosphohydrolase (PAPase) (EC. 3.1.3.4) in developing rabbit lung has been reported (21). The authors suggested that the endogenous diglycerides formed by the reaction of PAPase may be important in the regulation of PC synthesis in the developing lung. However, the specificity of fatty acids in diglycerides hats not been studied for PAPase, and PCGT in mammalian lung showed no specificity $(3,20,23)$. Therefore, the PC-1ysoPC cycle pathway may be a very important route for the formation of dipalmitoyl-PC. The marked increase of acylation of lysoPC at term and after birth indicates that this mechanism is at least temporarily related to lung maturation. However, its role in the formation of lung dipalmitoyl-PC, whether in the cytoplasm or in the endoplasmic reticulum, requires further study. A key enzyme in the cycle pathway. phospholipase $A_{2}$, also needs thorough investigation.

\section{CONCLUSION}

The protein concentration, phospholipid content, and the specific activities of CDP-choline pathway enzymes and PC-lysoPC cycle pathway enzymes in the developing rabbit lung have been studied. Total lung phospholipids, PC, and protein increased with maturation. The specific activities of $C D P$-choline enzymes (CK, CyT, and PCGT) decreased or remained the same with increasing gestational ages. In contrast, the specific activities of the PC-lysoPC cycle pathway enzymes (LPL, LAT, and acylCoA LAT) increased markedly at late gestational age, and continued to increase after birth to the maternal level, suggesting the importance of PC-lysoPC cycle pathway' in regulating synthesis and turnover with maturation.

\section{REFERENCES ANI NOTES}

1. Abe, M., Akino, T., and Ohno, $K$.: The formation of lecithin from lysolecithin in rat lung surfactant. Biochim. Biophys. Acta, 280: 275 (1972).

2. Abe, M., Ohno, K., and Soto, R.: Possible identity of Iysolecithin acylhydrolase with lysolecithin-lysolecithin acyltransferase in rat-lung soluble fraction. Biochim. Biophys. Actit, 369: 361 (1974).

3. Akino, T., Abe, M., and Arai, T.: Studies on the biosynthetic pathways of molecular species of lecithin by rat lung slices. Biochim. Biophys. Acta, 248: 274 (1971).

4. Chida, N., and Adams, F. H.: Incorporation of palmitate, glucose and choline into lecithin by fetal and newborn lamb lung. Pediat. Res., $1: 364$ (1967).

5. Dobiasova, M., and I Iaha, P.: Lysophospholipid metabolism in lung, liver and brown adipose tissue of the rat during development. Physiol. Bohemoslov. 17: $26(1968)$

6. Epstein, M. F., and Farrell, P. M.: The choline incorporation pathway: Primary mechanism for de novo lecithin synthesis in fetal primate lung. Pediat. Res., 9: 658 (1975).

7. Erbland, J. F., and Marinetti, G. V.: The enzymatic acylation and hydrolysis of lysolecithin. Biochim. Biophys. Acta 106: 128 (1965).

8. Farrell, P. M.: Regulation of pulmonary lecithin synthesis. In: C. A. Villec, D. B. Villee, and J. Zuckerman: Respiratory Distress Syndrome, p. 311 (Academic Press, New York, 1973).

9. Farrell, P. M., and Avery, M. E.: Hyaline membrane disease. Amer. Rev. Resp. Dis. 111: 657 (1975).

10. Farrell, P. M., Lundgren, D. W., and Adams, A. J.: Choline kinase and choline phosphotransferase in developing fetal rat lung. Biochem. Biophys. Res. Commun. 57: 696 (1974).

11. Frosolono, M. F., Slivka, S., and Charms, B. L.: Acyltransferase activities in dog lung microsomes. J. Lipid Res. 12: 96 (1971).

12. Gluck, L., Motoyama, E. K., Smits, H. L., and Kulovich, M. V.: The biochemical development of surface activity in mammalian lung $I$. The surface active phospholipids; the separation and distribution of surface active lecithin in the lung of the developing rabbit fetus. Pediat. Res. 1: 237 (1967).

13. Gluck, L. Sribney, M., and Kulovich, M.: The biochemical development of surface activity in mammalian lung. II. The biosynthesis of phospholipids in the lung of the developing rabbit fetus and newhorn. Pediat. Res. $1: 247$ $(1967)$.

14. Hallman, M., and Raivio, $K$.: Studies on the biosynthesis of disaturated lecithin of the lung: The importance of the lysolecithin pathway. Pediat. Res. 8: $874(1974)$.

15. Hallman, M., and Raivio, K.: Formation of disaturated lecithin through the lysolecithin pathway in the lung of the developing rabbit. Biol. Neonate 27: $329(1975)$.

16. Kyei-Aboagge, K., Rubinstein, D., and Beck, J. C.: Biosynthesis of dipalmitoyllecithin by the rabbit lung. Canad. J. Biochem. 51: 1581 (1973).

17. Lands, W. E. N1.: Metabolism of glycerolipids. II. The enzymatic acylation of lysolecithin. J. Biol. Chem. 235: 2233 (1960).

18. Layne, E.: Spectrophotometric and turbidimetric methods for measuring proicins. Methods Enzymol. 3: 450 (1957).

19. Rooncy, S. A., Wai-Lee, T. S., Gobran, L., and Motoyama, E. K.: Phospholipid content, composition and biosynthesis during fetal lung development in the rabhit. Biochim. Biophys. Acta $431:+47$ (1976).

20. Sarzala, M. G., and Van Golde, L. M. G.: Selective utilization of endogenous unsaturated phosphatidylcholine and diacylglyeerols by choline phosphotransferase of mouse lung microsomes. Biochim. Biophys. Acta, 411: $423(1976)$.

21. Schultz, F. M., Jimenez, J. M., MacDonald, P. C., and Johnston. J. M.: Fetal lung maturation. I. Phosphatidic acid phosphohydrolase in rabbit lung. Gynecol. Invest. 5: 222 (1974).

22. Tsao, F. H. C., and Zachman, R. D.: Phosphatidylcholine-lysophosphatidylcholine cycle pathway enzymes in rabbit lung. 1 . Subcellular localization and propertics. Pediat. Res., 11: 849 (1977).

23. Veryken, M. M., Montfoori, A., and Van Golde, L. M. G.: Some studies on the biosynthesis of the molecular species of phosphatidylcholine from rat lung and phosphatidylcholine and phosphatidylethanolamine from rat liver. Biochim. Biophys. Acta 260: 70 (1972).

24. Weinhold, P. A., Sanders, R., and Stern, W.: Regulation of choline phosphoglyceride synthesis during lung development in the rat. In: C. A. Villee, D. B. Villee, and J. Zuckerman: Respiratory Distress Syndrome, p. 29 (Academic Press, New York, 1973).

25. Weinhold, P. A., and Villee, C. A.: Phospholipid metabolism in the liver and lung of rats during development. Biochem. Biophys. Acta 106: $540(1965)$

26. Zachman, R. D.: The enzymes of lecithin biosynthesis in human newborn lungs. I. Choline kinase. Biol. Neonate. 19: 211 (1971).

27. Zachman, R. D.: The enzymes of lecithin biosynthesis in human newborn lungs. IIl. Phosphorylcholine glyceride transferase. Pediat. Res.. 7: 632 (1973).

28. This research was supported by National Institute of Health Grant 5-ROI HL 17239-02 11ED.

29. We wish to thank MIs. K. Jane Jaskowski and Mr. Steven IE. Louden for their technical assistance. The discussions with Dr. Gary R. Gutcher throughout this work and Dr. John H. Law's comments and suggestions on the manuscript are gratefully ach nowledged.

30. Requests for reprints should be addressed to: F. H. C. Tsao. Ph. D., Department of Pediatries, University of Wisconsin, and the Wisconsin Perinatal Center, 202 S. Park St., Madison. Wisc. 53715 (USA)

31. Received for publication September 23,1976.

32. Accepted for publication December 14, 1976. 